\title{
A framework for measuring the supply chain's agility of mass construction industry in Iran
}

\author{
Keyvan Poloie $^{\mathrm{a}^{*}}$, Safar Fazli ${ }^{\mathrm{b}}$, Mohsen Alvandi ${ }^{\mathrm{b}}$ and Somayeh Hasanlo ${ }^{\mathrm{c}^{*}}$
}

${ }^{a}$ Department of Industrial Management, Imam Khomeini International University (IKIU), Qazvin, Iran

${ }^{b}$ Assistant Professor, Department of Industrial Management, Imam Khomeini International University (IKIU), Qazvin, Iran ${ }^{c}$ Department of Industrial Managemen, Kar Higher Education Institute, Qazvin, Iran

\begin{tabular}{|c|c|}
\hline A R T I C LE I N F O & A B S TRACT \\
\hline $\begin{array}{l}\text { Article history: } \\
\text { Received May 14, } 2012 \\
\text { Received in Revised form } \\
\text { June, 26, } 2012 \\
\text { Accepted } 2 \text { August } 2012 \\
\text { Available online } \\
\text { August } 92012 \\
\text { Keywords: } \\
\text { Agile supply chain } \\
\text { Delphi approach } \\
\text { Descriptive structural modeling } \\
\text { Mass construction associations }\end{array}$ & $\begin{array}{l}\text { Impotent planning system in house providing process is the result of inadequate housing } \\
\text { management system in theoretical, empirical, and operational fields. In addition, Mass } \\
\text { Construction industry in Iran confronts with other problems such as instability in raw material } \\
\text { prices, unsteadiness in production and investment laws and regulations, frailty of transportation } \\
\text { infrastructure, international sanctions and etc. Furthermore, customers' needs, lower costs, and } \\
\text { greater customizations lead mass producing to search for new solutions and novel producing } \\
\text { system. Agility is offered as a strategy to enable Mass Construction associations to be } \\
\text { maintained in the competition of constantly changing market in Iran. In such a market, previous } \\
\text { approaches lose their capabilities in supply chain. Thus to achieve agility by Mass Construction } \\
\text { association is the chief aim of this study. This study is descriptive-analytic and can be identified } \\
\text { as developmental -functional considering its target. After surveying previous research literature } \\
\text { and using experts' opinions, we investigated final agile sub criteria of supply chain and then we } \\
\text { used interpretive- structural modeling approach to determine the relation among sub criteria and } \\
\text { to offer an agile supply chain model. Surveying research literature and experts' opinions lead us } \\
\text { to identify } 8 \text { criteria (society, government, financial, information technology, market, } \\
\text { partnership, quality and technology) and also } 22 \text { sub criteria for supply chain's agility. Then the } \\
\text { results were analyzed through interpretive-structural approach and relation of criteria and sub } \\
\text { criteria and their consequence were achieved. These relations showed that government and } \\
\text { infrastructure investment, culture, regulations and responses to social and environmental issues } \\
\text { are the basis of agility in mass housing productions' supply chain. This model helps supply } \\
\text { chain managers to have strategic planning to enhance agility in supply chain and find effective } \\
\text { sub criteria and criteria to invest on. }\end{array}$ \\
\hline
\end{tabular}

\section{Introduction}

Companies and associations struggle with two types of challenges: First the emergence of new technologies, which excludes old ones from the market and second, new demands for products by customers in great deal during a short time horizon. Associations are advised to make decisions promptly about their competitive conditions in the market. In compliance with recognition of this

* Corresponding author. Tel: +98-935-2430538

E-mail addresses: keyvan.poloie@yahoo.com (K. Poloie) 
trend, production process and services have moved towards a relatively new paradigm called "Agility". Unfortunately, the available scientific literature has defined agility as a general concept, which is only associated with manufacturing and producing (Maskell, 2001). The term "agile production" is traced back to a report named "Twenty first century's production organization strategy" by Iacocca's founder. In this report the concept of agility is referred to production organizations in order to obtain a secure competitive advantage (Rigby et al., 2000). To achieve a competitive qualification in an unsteady business environment, organizations must have accordance with customers and suppliers in order to attain acceptable agility through participation and partnership (Chiristopher \& Towill, 2002). An agile supply chain is able to response to changes properly in the work environment (Agarwal et al., 2007). Mass Construction Associations in Iran do not attend their supply chain; if they do, they can have the advantages of an agile supply chain (advantages such as predicting and detecting changing demands fast and easy) so Mass Construction Associations must identify the aspects and agile sub criteria and their effect on each other to reach the agile supply chain benefits. As a result, this study aims to find the way to know how Mass Construction Associations can attain agility in their supply chain. So it can be briefly said:

First: chain management supply is the competitive factor between organizations and the reason for profit increase and customers' satisfaction.

Second: agile supply chain approach is one of the most innovative and useful proposed approach in supply chain management in recent years and has been tested and developed in some organizations.

Third: there are still some unsolved issues related to agile supply chain especially in large companies.

Fourth: Mass Construction Associations in Iran have especial conditions to investigate supply chain, for example, the huge volume of investment, high cost of stopping house construction projects, etc. Agility plays a vital role in Mass Construction Associations in Iran where related authorities are willing to pay more money for being provided on time. In the second part of this study, we reviewed literature and theories. This part includes three sections, Supply Chain, Agility, and Supply Chain Agility. The third part or Research methodology explains the type of research, data collecting procedure and finishes with the explanation of Delphi and interpretive - structural modeling approaches. The fourth part presents the results and findings (achieved results through Delphi and ISM) and the final part presents conclusion and suggestion for further researches.

\section{Theoretical framework}

\subsection{Supply chain}

Supply chain management has become noticeable as a production paradigm in $21^{\text {st }}$ century in order to organizational competition (Gunasekaran et at., 2004). In previous decade, supply chain management has witnessed conspicuous growth in theories and practices. It is noteworthy that chain supply function evaluation has not received sufficient attention from researchers (Tam \& Tong, 2008). Many definitions have been offered by researchers, Chiristopher (2005) believes that supply chain is like a network consists of connected organizations with mutual dependency, which work together to control and manage the flow of goods from suppliers to customers. Stadtler and Kilger (2005) observed supply chain with organizational view, where chain is a special form of "network organization", which includes independent roles with equal right and its organizational structure corresponds with network organization's targets and expected tasks.

\subsection{Agility}

With the increasing unsteadiness and competiveness in the business environment, organizations need a comprehensive system where they are able to answer customers' needs. Customers desire constantly productions with more capability and large range of variety (Carlson \& Yao., 2008). 
Current organizations work in an unstable environment, which forces them to have compatible strategies. In fact, it has become a challenge for organizations, knowing how to be successful in unpredictable and changing environments. Among various strategies such as on time production, reengineering, virtual organizations and networking, organizational agility is the most favorite aspects. In such environments, agility affects organization's performance greatly (Ravichandran, 2007). The term "agility" literally means "to move fast", "to be active", "to have the ability to move fast and easy", "to be mentally quick", and "to be nimble" (Hornby, 2000). The term organizational agility's root is agile manufacturing which is introduced as responding to changes of business environment and transforming these changes to opportunities (Sterling, 2008). Agile manufacturing is applied to the organization's survival in a competitive environment where change is its main feature and the ability to respond customers' desire in a fluctuating market.

\subsection{Agile supply chain}

Traditional companies were assessed according to tangible assets such as buildings, machinery, and their stock in the past, since demands were always more than supply. Environments had stability, in contrast with today environments that are undergone changes. These changes are listed as below:

1.Instability in the market because of the altering market, cost pressure increase, developing competitiveness, and short-term development of new products,

2. Changes of customers' demands because of orderings, expecting high-quality products, and insisting on faster delivery,

3.Accelerating technological alterations which are obtained by innovative and efficient production facilities, and system's hardware and software integrity,

4.Changes in social issues emerged in order to environmental protection, work force's expectations, and legal pressure.

Based on earlier researches in previous decade about management science, Van Hoek (2001) identified two important issues associated with competitive quality achievement in modern business environment against mentioned changes. First companies must be united with suppliers, supplier with suppliers, customers, customers with customers in order to reduce their activities (Simchi-Levi et al., 2000). Consequently, individual companies cannot continue their activities individually because competition remains among those who have business partnership (Lambert et al., 1998; Christopher, 1998). Second, in a supply chain, companies must cooperate together to achieve an agile level before individual companies. All companies, suppliers, producers, distributors and customers may be involved in the process of supply chain acquiring (Jain \& Benyoucef, 2008).

Some scholars (Chiristopher, 2000; Van Hoek., 2001; Sharifi \& Zhang, 2000) state that it is hard to speculate the exact agility. To overcome this defect, supply chain is considered as an area where the concept of agility can be applied in actions. In total agility is the answer for "responding the customers", "people and information", "partnership among organizations" that are changing day by day. A chain should have excellent characteristics to achieve agility. It should have market sensitivity and be virtual and functionally integrated. These characteristics include organizations' relations in agile supply chain and the usage of information technology (Kisperska et al., 2008). The importance of connection with trading partners (customers, suppliers, service providers and competitors) in agile supply chain has been focused in many scientific researches. According to Bal et al. (1999) agile chain means "mutual partnership between buyers and suppliers, joint product development and joint information system". The classic integration does not exist in agile chain. Relations among organizations show the high level of enrichment and knowledge assimilation.

\subsection{Agile supply chain sub criteria}

Agile supply chain indicates the enhancement of compatibility, flexibility, ability to response, and quick and effective acting in unsteady markets. Agile supply chain has been noticed as a dominant 
paradigm in $21^{\text {st }}$ century as the winning strategy for organizations which are willing to lead market in national or international levels (Yusuf et al., 1999). Christopher is one of the scholars devoted his studies to agility and to its characteristics. In a study published in year 2000 he dedicated these features to agile supply chain: having market sensitivity, having virtual supply chain, interchanging electronic data, being functionally integrated, and betwork Based. He also offered an integrated enabling agile supply chain model in year 2001. Through three levels (principles, plans, and actions) he presents the mutual effect of agile logistics and agile production that results to agile supply chain (Chiristopher and Towill., 2001).

Agarwal et al. (2006) accomplished modeling for functional sub criteria of various supply chain such as lean and agile based on network analysis approach, and tested various functional aspects of supply chain like "market sensitivity", "functional integrated information", and "flexibility" with the use of various sub criteria on different supply chain paradigms. Fasial et al. (2006) categorized various supply chains based on two "customers' sensitivity", and "the ability to confront risks" axes. Many researchers have studied supply chain agility and in many of these researches, scholars have developed one aspect of supply chain agility. Bal et al. (1999), for instance, emphasized on virtual groups, Stratton and Warburton (2003), developed the role of inventory and capacity, Holweg (2005) pointed out the role of sensitivity and responses to existed trends in market, Swafford et al. (2006) emphasized on flexibility, and Svensson (2001) noted the role of enhancing trust within the network. Among the researchers only Power et al. (2001) tried to find the chief factors in a successful agile supply chain.

Furthermore, there have been other researchers who developed the concept of agility in supply chain in various industries such as agility in NOKIA (Collin et al., 2006). Some other people investigated the lean or agile supply chain in textile industry (Bruce et al., 2004). The others stressed on agile supply chain in Fashion (Christopher et al., 2004). Oloruntaba and Gray. (2006) developed supply chain of human aids as an agile supply chain. Chee et al. (2006) investigated the supply chain's responsiveness of an international toy company in a fluctuating seasonal conditions.

\section{Research methodology}

This is a descriptive, analytical and a developmental, functional one considering its targets. To establish this study we first reviewed the literature in order to acknowledge the theories and investigate the aspects and agile sub criteria of agile chain, and then we used interpretive modeling technique to determine the relation among aspects and sub criteria and to offer the mass housing production associations an agile supply chain model.

In this study, to finalize the investigated criteria and sub criteria for supply chain's agility, we used questionnaires according to ISM approach. The questionnaires were given to eleven experts and university scholars, chief managers who were experienced in mass housing production and agile supply chain. The study is question-oriented and seeks the answers through decision making techniques. The questions were:

1.What are the influential aspects and sub criteria in of Mass construction Associations' supply chain's agility?

2.Which of the aspects and sub criteria have the most effectiveness in agile supply chain model of Mass Construction Associations in Iran?

Collecting data was provided with adequate consistency and reliability. Because Delphi questionnaires were openly designed so any item and sub criteria could be added if needed. Interpretive - structural modeling technique was a part of the stages and since existed information was obtained by Delphi approach, there was no need to calculate the validity and reliability. 


\subsection{Methods of Data Analysis}

\subsubsection{Delphi approach}

In order to extract the criteria with the higher degree of importance Delphi questionnaires were used. Delphi approach has the ability to be investigated through general and advance methods. In this study, we used general method since it is more flexible. Delphi is a professional kind of survey to predict the future and based on it, we can obtain various results. Beside the simplicity of this method, it is highly reliable, so it can be used to collect the individuals' pure opinions and judgments.(Memarzade., 2012). According to descriptions, Delphi is a powerful process based on group relation structure, so that it can be used when we have the uncertain and incomplete knowledge (Hadar., 1995). Delphi approach has major application in cases with limitation of applicable law, formulas or mathematical models (Alvandi et al. 2011).

This method was first proposed by Helmer and Dalkey (1950) for Rand institute. It was used to investigate and collected the individuals and experts' views and judgments, without forcing them to be in a certain place, by giving questionnaires in several stages to unite their views. Ultimately, summing up, evaluating and analyzing views and individuals' ideas became the basis of targeting and planning or decision making. Delphi approach is a solution to create a group communication process in a way that it allows a group with independent and separate parts to anticipate in solving the problematic issues (Memarzade, 2012). In Delphi approach, questioning is performed within two stages or more and in each stage, the results of previous stage is used. Therefore, after second stage, experts and scholars answer the questions under the influence of previous results and other experts' view points (Lin et al., 2006; Alvandi et al., 2011).

\subsubsection{Interpretive - structural model (ISM)}

Interpretive - structural model (ISM) is used to identify inside relations among system variables. This method has been introduced by Warfield $(1976,1974)$ and is used to determine the priority and level of elements. To apply ISM technique, obtaining internal relation and priority of elements in a system must be done by the following process (Fazli et al., 2012)

First stage- determining used variables in the model: ISM starts with recognizing variables, which are related to the discussed issue.

Second stage - obtaining structural matrix of variables' internal relation (SSIM $\left.{ }^{1}\right)$ : after recognizing variables we must enter them in the structural matrix of variable's internal relation. This dimensions of the matrix well be equal to the number of variables. In its first row and column, variables are listed respectively. Then the relationship between each two variables is determined by symbols. These symbols are :

$V$ : variable $i$ will help to achieve variable $j ; A$ : variable $j$ will be achieved by variable $i$;

$X$ : variables $i$ and $j$ will help achieve each other; and $O$ : variables $j$ and $i$ are unrelated.

Third stage - obtaining Reachability matrix: with the SSIM matrix symbols transformation to zero and one, we can obtain Reachability matrix.

1. If the place $(j, i)$ in SSIM matrix is the symbol " $V$ ", it will be 1 in access matrix and be 0 in its symmetric place $(i, j)$.

2. If the place $(j, i)$ in SSIM matrix is the symbol " $A$ ", it will be 0 in access matrix and be 1 in its symmetric place $(i, j)$. 
3. If the place $(j, i)$ in SSIM matrix is the symbol " $X$ ", it will be 1 in access matrix and be 1 in its symmetric place $(i, j)$.

4. If the place $(j, i)$ in SSIM matrix is the symbol " $O$ ", it will be 0 in access matrix and be 0 in its symmetric place $(i, j)$.

Fourth stage- matrix compatibility (final Reachability matrix): after obtaining initial Reachability matrix, their internal consistency should be established. For example if variable 1 results in variable 2 , and variable 2 results in variable 3 , then variable 1 must result in variable 3 , and if this relation isn't applied in the access matrix, the matrix should be modified and the missed relations must be reconsidered. There are several approaches to make a matrix compatible, they are:

- First approach: if the matrix is not compatible, then experts' opinions should be recollected over and over again to achieve compatibility;

- Second approach: in this approach we use mathematical rules to have compatibility by multiplying it by $(\mathrm{K}+1)$ and $\mathrm{k} \geq 1$.

In this study we use second approach to have matrix compatibility (final Reachability matrix).

Fifth stage- determining level and priority of variables: to determine level and priority of variables, Reachability set and Antecedent set are established. Reachability set of each variable includes variables, which can be achieved by that variable, and Antecedent set includes variables that variable in Reachability set can be obtained by. This can be done by Reachability matrix. After determining Reachability and Antecedent set for each variable, the common elements in Reachability and Antecedent set are identified for each variable. Then after determining Antecedent set, Reachability and common elements, we find out the variables' level (factors). The highest leveled variable is the one with equal Reachability set and common elements.

Sixth stage-drawing the model: after determining relations and variables' level we can draw determinations through a model. Therefore, variables are ordered respectively, and then according to the table of values (Reachability and Antecedent set) we indentify relations among variables.

Seven stage- criteria classification according to driving Power and dependence power: in this part variables are subcategorized into 4 divisions. First division includes Autonomous Variable which have low driving power and dependency. These variables are not usually connected to the system and have weak relation to it. Second division is dedicated to dependent variables that have weak driving power but strong dependence power. Third division contains Linkage Variable with high driving power and strong dependence power. Fourth division includes independent variables with strong driving power and weak dependence power. They operate as foundation stones and must be emphasized before all to start working on the system.

\subsection{Applying ISM to determine the relation between sub criteria and criteria}

\subsubsection{Sub criteria and criteria of agility in supply chain}

According to literature review and previous studies, evaluation the agility of supply chains' Criteria and sub criteria of Mass Construction Associations in Iran is established in two ways as in Table 2 below: Comprehensively ( considering all models and opinions in this area) and Locally ( considering particular condition of companies in Iran). Despite the fact, there were 13 criteria and 45 sub criteria identified for agility of supply chain, after reviewing experts' opinions (Delphi method) and also according to Pareto Principle (80-20) the final number of sub criteria and criteria reached to 22 and, 8 respectively. 
Table 1

Effective Criteria on supply chain agility of Mass Construction associations

\begin{tabular}{|c|c|c|}
\hline Line & Criteria & Writers \& Experts \\
\hline 1 & Technology & Yusuf et al., 1999; Li Jin- Hai, 2003; Sharifi \& Zhang, 2000; Swafford, 2003; Ramesh \& Devadasan, 2007 \\
\hline 2 & Quality & $\begin{array}{l}\text { Yusuf et al., 1999; Khorshid, 2010; Lin et al., 2006; Ramesh \& Devadasan, 2007; Gunasekaran et al., 2001; Agarwal et } \\
\text { al., 2007; Van Hoek, 2001; Beamon \& Ware, 1998; Mason et al., 2000; Chiristopher \& Towill, 2001; Mason et al., } 2002\end{array}$ \\
\hline 3 & Partnership & Yusuf et al., 1999; Khorshid, 2010 \\
\hline 4 & Market & Agarwal et al., 2007; Yusuf et al., 1999; Van Hoek, 2001; Lin et al., 2006; Sharifi \& Zhang, 2000 , Khorshid, 2010 \\
\hline 5 & $\begin{array}{l}\text { Information } \\
\text { Technology }\end{array}$ & $\begin{array}{l}\text { Agarwal et al., 2007; Li Jin- Hai, 2003; Sharifi \& Zhang, 2000; Lin et al., 2006; Van Hoek, 2001; Khorshid, 2010; } \\
\text { Gunasekaran et al 2008; Ramesh \& Devadasan, 2007، Sharifi \& Zhang, 1999; Bal et al., 1999; Lee et al., 2000; } \\
\text { Chiristopher \& Towill, 2001; Helo, et al., 2006; Swafford, 2006; Jharkharia \& Shankar, 2004; Wong et al., 2006 }\end{array}$ \\
\hline 6 & Financial & Dove, 1996; Expert Opinion \\
\hline 7 & Government & Sherehiy et al., 2007 \\
\hline 8 & Society & Expert Opinion \\
\hline
\end{tabular}

Table 2

Effective sub criteria on supply chain agility of Mass Construction associations

\begin{tabular}{|c|c|c|}
\hline dimension & index & Writers \& Experts \\
\hline \multirow{3}{*}{ technology } & $\begin{array}{l}\text { Reduction of time because of modern technology } \\
\text { using }\end{array}$ & Expert Opinion \\
\hline & Improvement of design \& manufacture & Ramesh \& Devadasan, 2007; Expert Opinion \\
\hline & Cost effectiveness & $\begin{array}{l}\text { Li Jin- Hai , 2003; Swafford , 2003; Mason et al , 2000; Van Hoek et al., } \\
\text { 2001; Chiristopher \& Towill , 2001; Agarwal et al., 2007; }\end{array}$ \\
\hline \multirow{2}{*}{ quality } & Manufacturing quality & Agarwal et al , 2007; \\
\hline & Production compatibility with designing & Expert Opinion \\
\hline \multirow{3}{*}{ partnership } & the strategic relation between suppliers & $\begin{array}{l}\text { Agarwal et al., 2007; } \quad \text { Yusuf et al., 1999; Li Jin- Hai et al., 2003; } \\
\text { Khorshid, 2010; }\end{array}$ \\
\hline & Quick problem solving & Meredith \& Francis, 2000; \\
\hline & Logistic flexibility & Swafford, 2003; \\
\hline \multirow{6}{*}{ market } & House cost & Expert Opinion \\
\hline & House location & Expert Opinion \\
\hline & Customer's satisfaction & $\begin{array}{l}\text { Agarwal et al., 2007; Yusuf et al., 1999; Van Hoek, 2001; Li Jin-Hai, } \\
\text { 2003; Khorshid , 2010; } \text { Mason et al., 2000; }\end{array}$ \\
\hline & Market sensitivity & $\begin{array}{l}\text { Yusuf et al., 1999; Van Hoek, 2001; Chiristopher, 2000; Agarwal et al., } \\
\text { 2006; Li Jin-Hai, 2003; Chiristopher \& Towill, 2001; Agarwal et al., 2007; } \\
\text { Van Hoek , 2001; Chiristopher et al., 2004; Meredith \& Francis, 2000; } \\
\text { Fasial et al., 2006; Torng et al., 2004; Gunasekaran et al., 2008; Petro } \\
\text { Helo et al., 2006; Baker, } 2008\end{array}$ \\
\hline & Integrated information & Agarwal et al., 2007; Li et al., 2003; Van Hoek , 2001; \\
\hline & Accurate \& reliable information & Agarwal et al., 2007; Lin et al., 2006; Agarwal et al., 2006; \\
\hline \multirow{4}{*}{ Financial } & Basic investigation & Dove, 1996; Expert Opinion \\
\hline & Providing the budget on time & Expert Opinion \\
\hline & The financial capacity of clients & Expert Opinion \\
\hline & The financial capacity of contractors & Expert Opinion \\
\hline government & regulation & Hormozi , 2001; Expert Opinion \\
\hline \multirow{3}{*}{ society } & culture & Kearney , 2002; Dove , 1999; Expert Opinion \\
\hline & House owners' level & Expert Opinion \\
\hline & To response social \& environmental issues & Sherehiy et al., 2007; Li, 2003; Sharifi \& Zhang, 2000; Expert Opinion \\
\hline
\end{tabular}

\subsection{Obtaining variables’ structural internal relation matrix (SSIM)}

Identified criteria and sub criteria ( 8 criteria and 22 sub criteria) are mentioned in the first row and the column of the table for supply chains' agility of Mass Construction associations. The respondents were asked to determine the type of mutual relation among factors considering the indicated symbols. These questionnaires were given to 11 active managers in Mass Construction industry where 9 of them were completed. The achieved results, were handed to a group consisted of 3 chief managers to be finalized through a meeting.

Table 3

Structural Self- interaction matrix (SSIM) for Agility Criteria in Supply Chain

\begin{tabular}{llllllll}
\hline Criteria & 8 & 7 & 6 & 5 & 4 & 3 & 2 \\
\hline 1 & V & A & V & X & V & X & O \\
2 & X & A & A & A & V & A \\
3 & V & A & X & A & & \\
4 & A & A & A & A & & \\
5 & O & A & A & & & \\
6 & V & A & & & & \\
7 & V & & & & \\
\hline
\end{tabular}




\section{Table 4}

Structural Self- interaction matrix (SSIM) for Agility sub criteria In Supply Chain

\begin{tabular}{|c|c|c|c|c|c|c|c|c|c|c|c|c|c|c|c|c|c|c|c|c|c|}
\hline $\begin{array}{l}\text { Sub } \\
\text { criteria }\end{array}$ & 22 & 21 & 20 & 19 & 18 & 17 & 16 & 15 & 14 & 13 & 12 & 11 & 10 & 9 & 8 & 7 & 6 & 5 & 4 & 3 & 2 \\
\hline 1 & $\bar{O}$ & $\mathrm{O}$ & $\bar{O}$ & $\mathrm{O}$ & $\bar{O}$ & $\mathrm{O}$ & $\overline{\mathrm{A}}$ & $\mathrm{O}$ & $\mathrm{O}$ & $\mathrm{O}$ & $\mathrm{V}$ & $\mathrm{V}$ & $\mathrm{O}$ & $\mathrm{V}$ & $\mathrm{A}$ & $\bar{A}$ & $\bar{A}$ & $\overline{\mathrm{A}}$ & $\mathrm{O}$ & $\bar{V}$ & $\overline{\mathrm{A}}$ \\
\hline 2 & $\mathrm{O}$ & $\mathrm{V}$ & $\mathrm{O}$ & $\mathrm{O}$ & $\mathrm{O}$ & $\mathrm{O}$ & $\mathrm{O}$ & $\mathrm{O}$ & $\mathrm{O}$ & $\mathrm{O}$ & $\mathrm{O}$ & $\mathrm{O}$ & $\mathrm{O}$ & $\mathrm{O}$ & $\mathrm{O}$ & $\mathrm{O}$ & A & A & $\mathrm{V}$ & V & \\
\hline 3 & $\mathrm{O}$ & $\mathrm{O}$ & $\mathrm{O}$ & $\mathrm{O}$ & $\mathrm{O}$ & $\mathrm{O}$ & A & $\mathrm{O}$ & $\mathrm{O}$ & $\mathrm{O}$ & $\mathrm{O}$ & $\mathrm{O}$ & $\mathrm{O}$ & $\mathrm{V}$ & $\mathrm{A}$ & A & A & A & $\mathrm{X}$ & & \\
\hline 4 & $\mathrm{O}$ & $\mathrm{O}$ & $\mathrm{O}$ & $\mathrm{O}$ & $\mathrm{O}$ & $\mathrm{O}$ & $\mathrm{O}$ & $\mathrm{O}$ & $\mathrm{O}$ & $\mathrm{O}$ & V & V & $\mathrm{O}$ & V & $\mathrm{O}$ & $\mathrm{O}$ & $\mathrm{O}$ & A & & & \\
\hline 5 & $\mathrm{O}$ & $\mathrm{O}$ & $\mathrm{O}$ & $\mathrm{O}$ & $\mathrm{O}$ & O & $\mathrm{O}$ & O & O & O & $\mathrm{O}$ & $\mathrm{O}$ & O & $\mathrm{O}$ & $\mathrm{O}$ & $\mathrm{O}$ & A & & & & \\
\hline 6 & $\mathrm{O}$ & $\mathrm{O}$ & A & A & $\mathrm{O}$ & $\mathrm{O}$ & $\mathrm{O}$ & $\mathrm{O}$ & A & A & $\mathrm{O}$ & $\mathrm{O}$ & $\mathrm{O}$ & $\mathrm{O}$ & $X$ & A & & & & & \\
\hline 7 & $\mathrm{O}$ & $\mathrm{O}$ & A & $\mathrm{O}$ & $\mathrm{O}$ & $\mathrm{O}$ & $X$ & $\mathrm{O}$ & A & A & $\mathrm{O}$ & $\mathrm{O}$ & $\mathrm{O}$ & $\mathrm{O}$ & $\mathrm{X}$ & & & & & & \\
\hline 8 & $\mathrm{O}$ & $\mathrm{O}$ & $\mathrm{O}$ & $\mathrm{A}$ & $\mathrm{O}$ & $\mathrm{O}$ & X & $\mathrm{O}$ & $\mathrm{A}$ & $\mathrm{A}$ & $\mathrm{O}$ & $\mathrm{O}$ & $\mathrm{O}$ & $\mathrm{O}$ & & & & & & & \\
\hline 9 & $\mathrm{O}$ & $\mathrm{A}$ & $\mathrm{O}$ & O & $\mathrm{O}$ & O & $\mathrm{O}$ & $\mathrm{O}$ & $\mathrm{O}$ & $\mathrm{O}$ & V & V & A & & & & & & & & \\
\hline 10 & A & A & $\mathrm{O}$ & $\mathrm{O}$ & $\mathrm{O}$ & $\mathrm{O}$ & $\mathrm{O}$ & $\mathrm{O}$ & A & $\mathrm{O}$ & V & $\mathrm{O}$ & & & & & & & & & \\
\hline 11 & $\mathrm{O}$ & $\mathrm{O}$ & $\mathrm{O}$ & $\mathrm{O}$ & $\mathrm{O}$ & $\mathrm{O}$ & $\mathrm{O}$ & $\mathrm{O}$ & $\mathrm{O}$ & $\mathrm{O}$ & $X$ & & & & & & & & & & \\
\hline 12 & $\mathrm{O}$ & $\mathrm{O}$ & $\mathrm{O}$ & $\mathrm{O}$ & $\mathrm{O}$ & $\mathrm{O}$ & $\mathrm{O}$ & $\mathrm{O}$ & $\mathrm{O}$ & $\mathrm{O}$ & & & & & & & & & & & \\
\hline 13 & $\mathrm{O}$ & $\mathrm{O}$ & $\mathrm{O}$ & A & $\mathrm{O}$ & $\mathrm{O}$ & $\mathrm{V}$ & $\mathrm{A}$ & $\mathrm{O}$ & & & & & & & & & & & & \\
\hline 14 & A & $\mathrm{O}$ & A & A & $\mathrm{O}$ & $\mathrm{O}$ & $\mathrm{V}$ & A & & & & & & & & & & & & & \\
\hline 15 & $\mathrm{O}$ & $\mathrm{V}$ & V & A & $\mathrm{O}$ & $\mathrm{O}$ & $\mathrm{O}$ & & & & & & & & & & & & & & \\
\hline 16 & $\mathrm{O}$ & $\mathrm{O}$ & $\mathrm{O}$ & $\mathrm{O}$ & A & A & & & & & & & & & & & & & & & \\
\hline 17 & O & $\mathrm{O}$ & $\mathrm{O}$ & $\mathrm{O}$ & $\mathrm{O}$ & & & & & & & & & & & & & & & & \\
\hline 18 & $\mathrm{O}$ & $\mathrm{O}$ & $\mathrm{O}$ & $\mathrm{O}$ & & & & & & & & & & & & & & & & & \\
\hline 19 & V & $\mathrm{O}$ & $X$ & & & & & & & & & & & & & & & & & & \\
\hline 20 & $\mathrm{O}$ & $\mathrm{V}$ & & & & & & & & & & & & & & & & & & & \\
\hline 21 & O & & & & & & & & & & & & & & & & & & & & \\
\hline
\end{tabular}

\subsection{Obtaining the reachability matrix}

According to mentioned regulation in methodology and with converting the symbols of structural matrix' relation to 0 and 1 , the obtained initial reachability matrix will be shown in Table 5 .

Table 5

Initial reachability matrix for agility criteria in supply chain

\begin{tabular}{lllllllll}
\hline Criteria & 8 & 7 & 6 & 5 & 4 & 3 & 2 & 1 \\
\hline 1 & 1 & 0 & 1 & 1 & 1 & 1 & 0 & 1 \\
2 & 1 & 0 & 0 & 0 & 1 & 0 & 0 & 1 \\
3 & 1 & 0 & 1 & 0 & 1 & 1 & 0 & 0 \\
4 & 0 & 0 & 0 & 0 & 1 & 0 & 1 & 1 \\
5 & 0 & 0 & 0 & 1 & 1 & 1 & 1 & 1 \\
6 & 1 & 0 & 1 & 1 & 1 & 1 & 1 & 1 \\
7 & 1 & 1 & 1 & 1 & 1 & 1 & 1 & 0 \\
8 & 1 & 0 & 0 & 0 & 1 & 0 & & 1 \\
\hline
\end{tabular}

\section{Table 6}

Initial reachability matrix for Agility sub criteria In Supply Chain

\begin{tabular}{llllllllllllllllllllllllllll}
\hline sub criteria & 22 & 21 & 20 & 19 & 18 & 17 & 16 & 15 & 14 & 13 & 12 & 11 & 10 & 9 & 8 & 7 & 6 & 5 & 4 & 3 & 2 & 1 \\
\hline 1 & 0 & 0 & 0 & 0 & 0 & 0 & 0 & 0 & 0 & 0 & 1 & 1 & 0 & 1 & 0 & 0 & 0 & 0 & 0 & 1 & 0 & 1 \\
2 & 0 & 1 & 0 & 0 & 0 & 0 & 0 & 0 & 0 & 0 & 0 & 0 & 0 & 0 & 0 & 0 & 0 & 0 & 1 & 1 & 1 & 1 \\
3 & 0 & 0 & 0 & 0 & 0 & 0 & 0 & 0 & 0 & 0 & 0 & 0 & 0 & 1 & 0 & 0 & 0 & 0 & 1 & 1 & 0 & 0 \\
4 & 0 & 0 & 0 & 0 & 0 & 0 & 0 & 0 & 0 & 0 & 1 & 1 & 0 & 1 & 0 & 0 & 0 & 0 & 1 & 1 & 0 & 0 & 0 \\
5 & 0 & 0 & 0 & 0 & 0 & 0 & 0 & 0 & 0 & 0 & 0 & 0 & 0 & 0 & 0 & 0 & 0 & 1 & 0 & 1 & 1 & 1 \\
6 & 0 & 0 & 0 & 0 & 0 & 0 & 0 & 0 & 0 & 0 & 0 & 0 & 0 & 0 & 1 & 0 & 1 & 1 & 0 & 1 & 1 & 1 \\
7 & 0 & 0 & 0 & 0 & 0 & 0 & 1 & 0 & 0 & 0 & 0 & 0 & 0 & 0 & 1 & 1 & 1 & 0 & 0 & 1 & 0 & 1 \\
8 & 0 & 0 & 0 & 0 & 0 & 0 & 1 & 0 & 0 & 0 & 0 & 0 & 0 & 0 & 1 & 1 & 1 & 0 & 0 & 1 & 0 & 1 \\
9 & 0 & 0 & 0 & 0 & 0 & 0 & 0 & 0 & 0 & 0 & 1 & 1 & 0 & 1 & 0 & 0 & 0 & 0 & 0 & 0 & 0 & 0 \\
10 & 0 & 0 & 0 & 0 & 0 & 0 & 0 & 0 & 0 & 0 & 1 & 0 & 1 & 1 & 0 & 0 & 0 & 0 & 0 & 0 & 0 & 0 \\
11 & 0 & 0 & 0 & 0 & 0 & 0 & 0 & 0 & 0 & 0 & 1 & 1 & 0 & 0 & 0 & 0 & 0 & 0 & 0 & 0 & 0 & 0 \\
12 & 0 & 0 & 0 & 0 & 0 & 0 & 0 & 0 & 0 & 0 & 1 & 1 & 0 & 0 & 0 & 0 & 0 & 0 & 0 & 0 & 0 & 0 \\
13 & 0 & 0 & 0 & 0 & 0 & 0 & 1 & 0 & 0 & 1 & 0 & 0 & 0 & 0 & 1 & 1 & 1 & 0 & 0 & 0 & 0 & 0 \\
14 & 0 & 0 & 0 & 0 & 0 & 0 & 1 & 0 & 1 & 0 & 0 & 0 & 1 & 0 & 1 & 1 & 1 & 0 & 0 & 0 & 0 & 0 \\
15 & 0 & 1 & 1 & 0 & 0 & 0 & 0 & 1 & 1 & 1 & 0 & 0 & 0 & 0 & 0 & 0 & 0 & 0 & 0 & 0 & 0 & 0 \\
16 & 0 & 0 & 0 & 0 & 0 & 0 & 1 & 0 & 0 & 0 & 0 & 0 & 0 & 0 & 1 & 1 & 0 & 0 & 0 & 1 & 0 & 1 \\
17 & 0 & 0 & 0 & 0 & 0 & 1 & 1 & 0 & 0 & 0 & 0 & 0 & 0 & 0 & 0 & 0 & 0 & 0 & 0 & 0 & 0 & 0 \\
18 & 0 & 0 & 0 & 0 & 1 & 0 & 1 & 0 & 0 & 0 & 0 & 0 & 0 & 0 & 0 & 0 & 0 & 0 & 0 & 0 & 0 & 0 \\
19 & 1 & 0 & 1 & 1 & 0 & 0 & 0 & 1 & 1 & 1 & 0 & 0 & 0 & 0 & 1 & 0 & 1 & 0 & 0 & 0 & 0 & 0 \\
20 & 0 & 1 & 1 & 1 & 0 & 0 & 0 & 0 & 1 & 0 & 0 & 0 & 0 & 0 & 0 & 1 & 1 & 0 & 0 & 0 & 0 & 0 \\
21 & 0 & 1 & 0 & 0 & 0 & 0 & 0 & 0 & 0 & 0 & 0 & 0 & 1 & 1 & 0 & 0 & 0 & 0 & 0 & 0 & 0 & 0 \\
22 & 1 & 0 & 0 & 0 & 0 & 0 & 0 & 0 & 1 & 0 & 0 & 0 & 1 & 0 & 0 & 0 & 0 & 0 & 0 & 0 & 0 & 0 \\
\hline
\end{tabular}

\subsection{Making the matrix compatible (final reachablility matrix)}

In this study, we used mathematical approach; the results can be seen in Table 7 . In this table the numbers which are marked with $*$, indicate that there were 0 in initial reachability matrix and after compatibility they have become 1 . 
Table 7

Final reachability matrix for Agility Criteria In Supply Chain

\begin{tabular}{lllllllll}
\hline Criteria & 8 & 7 & 6 & 5 & 4 & 3 & 2 & 1 \\
\hline 1 & 1 & 0 & 1 & 1 & 1 & 1 & $* 1$ & 1 \\
2 & 1 & 0 & 0 & 0 & 1 & 0 & 1 & 0 \\
3 & 1 & 0 & 1 & $* 1$ & 1 & 1 & 1 & 1 \\
4 & 0 & 0 & 0 & 0 & 1 & 0 & 0 & 0 \\
5 & $* 1$ & 0 & $* 1$ & 1 & 1 & 1 & 1 & 1 \\
6 & 1 & 0 & 1 & 1 & 1 & 1 & 1 & $* 1$ \\
7 & 1 & 1 & 1 & 1 & 1 & 1 & 1 & 1 \\
\hline
\end{tabular}

\section{Table 8}

Final reachability matrix for Agility sub criteria In Supply Chain

\begin{tabular}{|c|c|c|c|c|c|c|c|c|c|c|c|c|c|c|c|c|c|c|c|c|c|c|}
\hline $\begin{array}{l}\text { sub } \\
\text { criteria }\end{array}$ & 22 & 21 & 20 & 19 & 18 & 17 & 16 & 15 & 14 & 13 & 12 & 11 & 10 & 9 & 8 & 7 & 6 & 5 & 4 & 3 & 2 & 1 \\
\hline 1 & 0 & 0 & 0 & 0 & 0 & 0 & 0 & 0 & 0 & 0 & 1 & 1 & 0 & 1 & 0 & 0 & 0 & 0 & $* 1$ & 1 & 0 & 1 \\
\hline 2 & 0 & 1 & 0 & 0 & 0 & 0 & 0 & 0 & 0 & 0 & $* 1$ & $* 1$ & $* 1$ & $* 1$ & 0 & 0 & 0 & 0 & 1 & 1 & 1 & 1 \\
\hline 3 & 0 & 0 & 0 & 0 & 0 & 0 & 0 & 0 & 0 & 0 & $* 1$ & $* 1$ & 0 & 1 & 0 & 0 & 0 & 0 & 1 & 1 & 0 & 0 \\
\hline 4 & 0 & 0 & 0 & 0 & 0 & 0 & 0 & 0 & 0 & 0 & 1 & 1 & 0 & 1 & 0 & 0 & 0 & 0 & 1 & 1 & 0 & 0 \\
\hline 5 & 0 & $* 1$ & 0 & 0 & 0 & 0 & 0 & 0 & 0 & 0 & $1 *$ & $* 1$ & $* 1$ & $* 1$ & 1 & 0 & 0 & 0 & $* 1$ & 1 & 1 & 1 \\
\hline 6 & 0 & $* 1$ & 0 & 0 & 0 & 0 & $* 1$ & 0 & 0 & 0 & $* 1$ & $1 *$ & $1^{*}$ & $1 *$ & 1 & $1^{*}$ & 1 & 1 & $1 *$ & 1 & 1 & 1 \\
\hline 7 & 0 & $* 1$ & 0 & 0 & 0 & 0 & 1 & 0 & 0 & 0 & $* 1$ & $1^{*}$ & $1^{*}$ & $1 *$ & 1 & 1 & 1 & $1 *$ & $1^{*}$ & 1 & $1 *$ & 1 \\
\hline 8 & 0 & $* 1$ & 0 & 0 & 0 & 0 & 1 & 0 & 0 & 0 & $* 1$ & $1 *$ & $1^{*}$ & $1 *$ & 1 & 1 & 1 & $1 *$ & $1 *$ & 1 & $1 *$ & 1 \\
\hline 9 & 0 & 0 & 0 & 0 & 0 & 0 & 0 & 0 & 0 & 0 & 1 & 1 & 0 & 1 & 0 & 0 & 0 & 0 & 0 & 0 & 0 & 0 \\
\hline 10 & 0 & 0 & 0 & 0 & 0 & 0 & 0 & 0 & 0 & 0 & 1 & $1 *$ & 1 & 1 & 0 & 0 & 0 & 0 & 0 & 0 & 0 & 0 \\
\hline 11 & 0 & 0 & 0 & 0 & 0 & 0 & 0 & 0 & 0 & 0 & 1 & 1 & 0 & 0 & 0 & 0 & 0 & 0 & 0 & 0 & 0 & 0 \\
\hline 12 & 0 & 0 & 0 & 0 & 0 & 0 & 0 & 0 & 0 & 0 & 1 & 1 & 0 & 0 & 0 & 0 & 0 & 0 & 0 & 0 & 0 & 0 \\
\hline 13 & 0 & $1^{*}$ & 0 & 0 & 0 & 0 & 1 & 0 & 0 & 1 & $1 *$ & $1^{*}$ & $1^{*}$ & $1 *$ & 1 & 1 & 1 & $1^{*}$ & $1^{*}$ & $1^{*}$ & $1^{*}$ & $1^{*}$ \\
\hline 14 & 0 & $1 *$ & 0 & 0 & 0 & 0 & 1 & 0 & 1 & 0 & $1 *$ & $1 *$ & $1^{*}$ & $1 *$ & 1 & 1 & 1 & $1^{*}$ & $1 *$ & $1 *$ & $1 *$ & $1 *$ \\
\hline 15 & $1 *$ & 1 & 1 & $1 *$ & 0 & 0 & $1 *$ & 1 & 1 & 1 & $1 *$ & $1^{*}$ & $1^{*}$ & $1 *$ & $1 *$ & $1^{*}$ & $1^{*}$ & $1 *$ & $1 *$ & $1^{*}$ & $1 *$ & $1 *$ \\
\hline 16 & 0 & 1 & 0 & 0 & 0 & 0 & 1 & 0 & 0 & 0 & $1 *$ & $1 *$ & $1^{*}$ & $1 *$ & 1 & 1 & $1 *$ & $1 *$ & $1 *$ & $1 *$ & $1 *$ & $1 *$ \\
\hline 17 & 0 & 1 & 0 & 0 & 0 & 1 & 1 & 0 & 0 & 0 & $1 *$ & $1 *$ & $1^{*}$ & $1 *$ & $1 *$ & $1^{*}$ & $1^{*}$ & $1^{*}$ & 1 & $1 *$ & $1 *$ & $1^{*}$ \\
\hline 18 & 0 & $1 *$ & 0 & 0 & 1 & 0 & 1 & 0 & 0 & 0 & $1^{*}$ & $1 *$ & $1^{*}$ & $1 *$ & $1 *$ & $1^{*}$ & $1 *$ & $1^{*}$ & $1 *$ & $1 *$ & $1 *$ & $1^{*}$ \\
\hline 19 & 1 & $1^{*}$ & 1 & 1 & 0 & 0 & $1 *$ & 1 & 1 & 1 & $1^{*}$ & $1 *$ & $1^{*}$ & $1 *$ & $1^{*}$ & $1^{*}$ & 1 & $1^{*}$ & $1^{*}$ & $1^{*}$ & $1 *$ & $1^{*}$ \\
\hline 20 & $1 *$ & 1 & 1 & 1 & 0 & 0 & $1 *$ & 1 & 1 & $1 *$ & $1 *$ & $1 *$ & $1^{*}$ & $1 *$ & $1 *$ & 1 & 1 & $1 *$ & $1 *$ & $1 *$ & $1 *$ & $1^{*}$ \\
\hline 21 & 0 & 1 & 0 & 0 & 0 & 0 & 0 & 0 & 0 & 0 & $1 *$ & $1 *$ & 1 & 1 & 0 & 0 & 0 & 0 & 0 & 0 & 0 & 0 \\
\hline 22 & 1 & $1 *$ & 0 & 0 & 0 & 0 & $1 *$ & 0 & 1 & 0 & $1 *$ & $1 *$ & $1^{*}$ & $1 *$ & $1 *$ & $1 *$ & $1 *$ & 1* & $1 *$ & $1 *$ & $1 *$ & $1^{*}$ \\
\hline
\end{tabular}

\subsection{Determining variables' levels and priorities}

In current study through four tables, four levels of criteria and through nine tables nine levels of sub criteria of Mass Construction Association's supply chain's agility were obtained, as are presented in table below:

\section{Table 9}

Four Levels of Agility Criteria in Supply Chain

\begin{tabular}{llllll}
\hline \multirow{2}{*}{ line } & \multirow{2}{*}{ Criteria } & $\begin{array}{l}\text { Reachability set: } \\
\mathrm{R}(\mathrm{Pi})\end{array}$ & $\begin{array}{l}\text { Antecedent set: } \\
\mathrm{A}(\mathrm{Pi})\end{array}$ & $\begin{array}{l}\text { Intersection: } \\
\mathrm{R}(\mathrm{Pi}) \cap \mathrm{A}(\mathrm{Pi})\end{array}$ & Level \\
\hline 1 & Technology & $12,3,4,5,6,8$, & $13,5,6,7$, & $13,5,6$, & III \\
2 & quality & $2,4,8$ & $1,2,3,5,6,7,8$ & 2,8 & II \\
3 & partnership & $1,2,3,4,5,6,8$ & $1,3,5,6,7$ & $1,3,5$ & III \\
4 & market & 4 & $1,2,3,4,5,6,7,8$ & 4 & I \\
5 & Information technology & $1,2,3,4,5,6,8$ & $1,3,5,6,7$ & $1,3,5,6$ & III \\
6 & financial & $1,2,3,4,5,6,8$ & $1,3,5,6,7$ & $1,3,5,6$ & III \\
7 & government & $1,2,3,4,5,6,7,8$ & 7 & 7 & IV \\
8 & Society & $2,4,8$ & $1,2,3,5,6,7,8$ & 2,8 & II \\
\hline
\end{tabular}




\section{Table 10}

Nine levels of Agility sub criteria in Supply Chain

\begin{tabular}{|c|c|c|c|c|c|}
\hline line & sub criteria & $\begin{array}{l}\text { Reachability set: } \\
\mathrm{R}(\mathrm{Pi})\end{array}$ & $\begin{array}{l}\text { Antecedent set: } \\
\mathrm{A}(\mathrm{Pi})\end{array}$ & $\begin{array}{l}\text { Intersection: } \\
\mathrm{R}(\mathrm{Pi}) \cap \mathrm{A}(\mathrm{Pi}) \\
\end{array}$ & Level \\
\hline 1 & $\begin{array}{l}\text { Time } \\
\text { reduction } \\
\text { because of } \\
\text { modern } \\
\text { technology } \\
\text { using }\end{array}$ & 12119431 & $1,2,5,6,7,8,13,14,15,16,17,18,19,20,22$ & 1 & IV \\
\hline 2 & $\begin{array}{l}\text { Design and } \\
\text { manufacture } \\
\text { improvement }\end{array}$ & $2112119610431 ، 2$ & $2,5,6,7,8,13,14,15,16,17,18,19,20,22$ & 2 & $\mathrm{~V}$ \\
\hline 3 & $\begin{array}{l}\text { Cost } \\
\text { effectiveness }\end{array}$ & $3,4,9,11,12$ & $1,2,3,4,5,6,7,8,13,14,15,16,17,18,19,20,22$ & 3,4 & III \\
\hline 4 & $\begin{array}{l}\text { Manufacturin } \\
\text { g quality }\end{array}$ & $3,4,9,11,12$ & $1,2,3,4,5,6,7,8,13,14,15,16,17,18,19,20,22$ & 3,4 & III \\
\hline 5 & $\begin{array}{l}\text { Production } \\
\text { compatibility } \\
\text { with } \\
\text { designing }\end{array}$ & $1,2,3,4,5,9,10,11,12,21$ & $5,6,7,8,13,14,15,16,17,18,19,20,22$ & 5 & VI \\
\hline 6 & $\begin{array}{l}\text { Suppliers' } \\
\text { strategic } \\
\text { relation }\end{array}$ & $1,2,3,4,5,6,7,8,9,10,11,12,16,21$ & $6,7,8,13,14,15,16,17,18,19,20,22$ & $6,7,8,16$ & VII \\
\hline 7 & $\begin{array}{l}\text { Quick } \\
\text { problem } \\
\text { solving }\end{array}$ & $1,2,3,4,5,6,7,8,9,10,11,12,16,21$ & $6,7,8,13,14,15,16,17,18,19,20,22$ & $6,7,8,16$ & VII \\
\hline 8 & $\begin{array}{l}\text { Logistic } \\
\text { flexibility }\end{array}$ & $1,2,3,4,5,6,7,8,9,10,11,12,16,21$ & $6,7,8,13,14,15,16,17,18,19,20,22$ & $6,7,8,16$ & VII \\
\hline 9 & House cost & $9,11,12$ & $\begin{array}{l}1,2,3,4,5,6,7,8,9,10,13,14,15,16,17,18,19,20 \\
21,22\end{array}$ & 9 & II \\
\hline 10 & $\begin{array}{l}\text { House } \\
\text { location }\end{array}$ & $9,10,11,12$ & $\begin{array}{l}2,3,4,5,6,7,8,9,10,13,14,15,16,17,18,19,20,21 \\
, 22\end{array}$ & 10 & III \\
\hline 11 & $\begin{array}{l}\text { Customer's } \\
\text { satisfaction }\end{array}$ & 11,12 & $\begin{array}{l}1,2,3,4,5,6,7,8,9,10,11,12,13,14,15,16,17,18 \\
19,20,21,22\end{array}$ & 11,12 & I \\
\hline 12 & $\begin{array}{l}\text { Market } \\
\text { sensitivity }\end{array}$ & 11,12 & $\begin{array}{l}1,2,3,4,5,6,7,8,9,10,11,12,13,14,15,16,17,18 \\
19,20,21,22\end{array}$ & 11,12 & I \\
\hline 13 & $\begin{array}{l}\text { Integrated } \\
\text { information }\end{array}$ & $1,2,3,4,5,6,7,8,9,10,11,12,13,16,21$ & $13,15,19,20$ & 13 & VIII \\
\hline 15 & $\begin{array}{l}\text { Basic } \\
\text { investigation }\end{array}$ & $\begin{array}{l}1,2,3,4,5,6,7,8,9,10,11,12,13,14,15,16,19,20,21 \\
, 22\end{array}$ & $15,19,20$ & $15,19,20$ & IX \\
\hline 16 & $\begin{array}{l}\text { On-time } \\
\text { budget } \\
\text { providing }\end{array}$ & $1,2,3,4,5,6,7,8,9,10,11,12,16,21$ & $6,7,8,13,14,15,16,17,18,19,20,22$ & $6,7,8,16$ & VI \\
\hline 17 & $\begin{array}{l}\text { Clients' } \\
\text { financial } \\
\text { capacity }\end{array}$ & $1,2,3,4,5,6,7,8,9,10,11,12,16,17,21$ & 17 & 17 & VIII \\
\hline 18 & $\begin{array}{l}\text { Contractors' } \\
\text { financial } \\
\text { capacity }\end{array}$ & $1,2,3,4,5,6,7,8,9,10,11,12,16,18,21$ & 18 & 18 & VIII \\
\hline 19 & Regulation & $\begin{array}{l}1,2,3,4,5,6,7,8,9,10,11,12,13,14,15,16,19,20,21 \\
, 22\end{array}$ & $15,19,20$ & $15,19,20$ & IX \\
\hline 20 & Culture & $\begin{array}{l}1,2,3,4,5,6,7,8,9,10,11,12,13,14,15,16,19,20,21 \\
, 22\end{array}$ & $15,19,20$ & $15,19,20$ & IX \\
\hline 21 & $\begin{array}{l}\text { House } \\
\text { owners' level }\end{array}$ & $9,10,11,12,21$ & $2,5,6,7,8,13,14,15,16,17,18,19,20,21,22$ & 21 & IV \\
\hline 22 & $\begin{array}{l}\text { Responsibilit } \\
\mathrm{y} \text { for social } \\
\text { and } \\
\text { environmenta } \\
1 \text { issues }\end{array}$ & $1,2,3,4,5,6,7,8,9,10,11,12,14,16,21,22$ & $15,19,20,22$ & 22 & IX \\
\hline
\end{tabular}

\subsection{Drawing the model}

In this study, criteria are represented in four levels. In the highest level, the variable "Market" has 4 values and in the lowest level, the variable "Government" operates like a base for this model. 


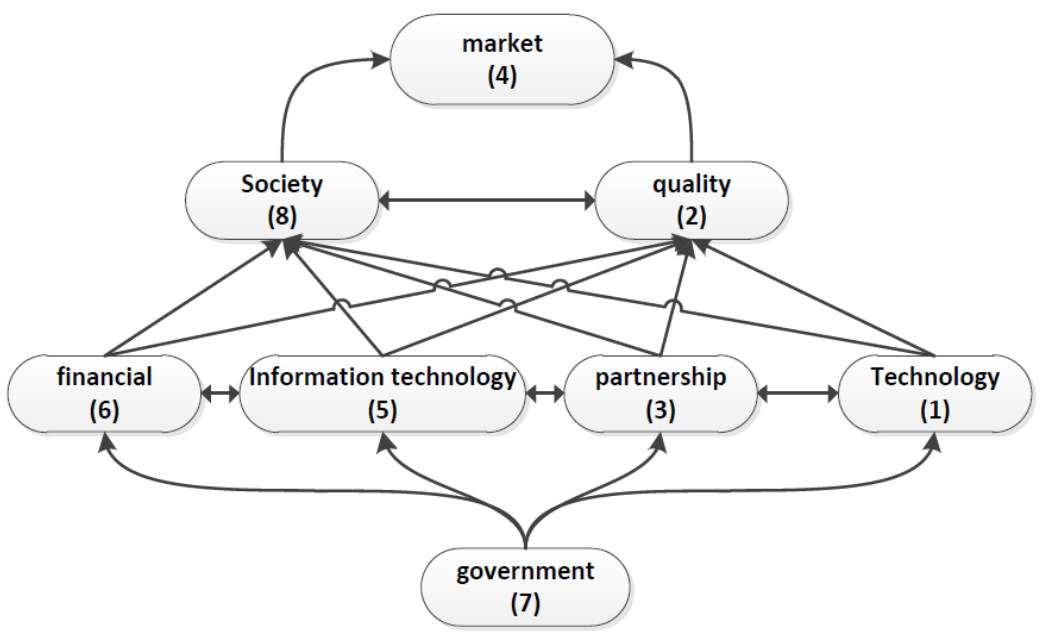

Level I

Level II

Level III

Level IV

Fig. 1. The relation between influential Criteria of Mass Construction association's supply chain's agility

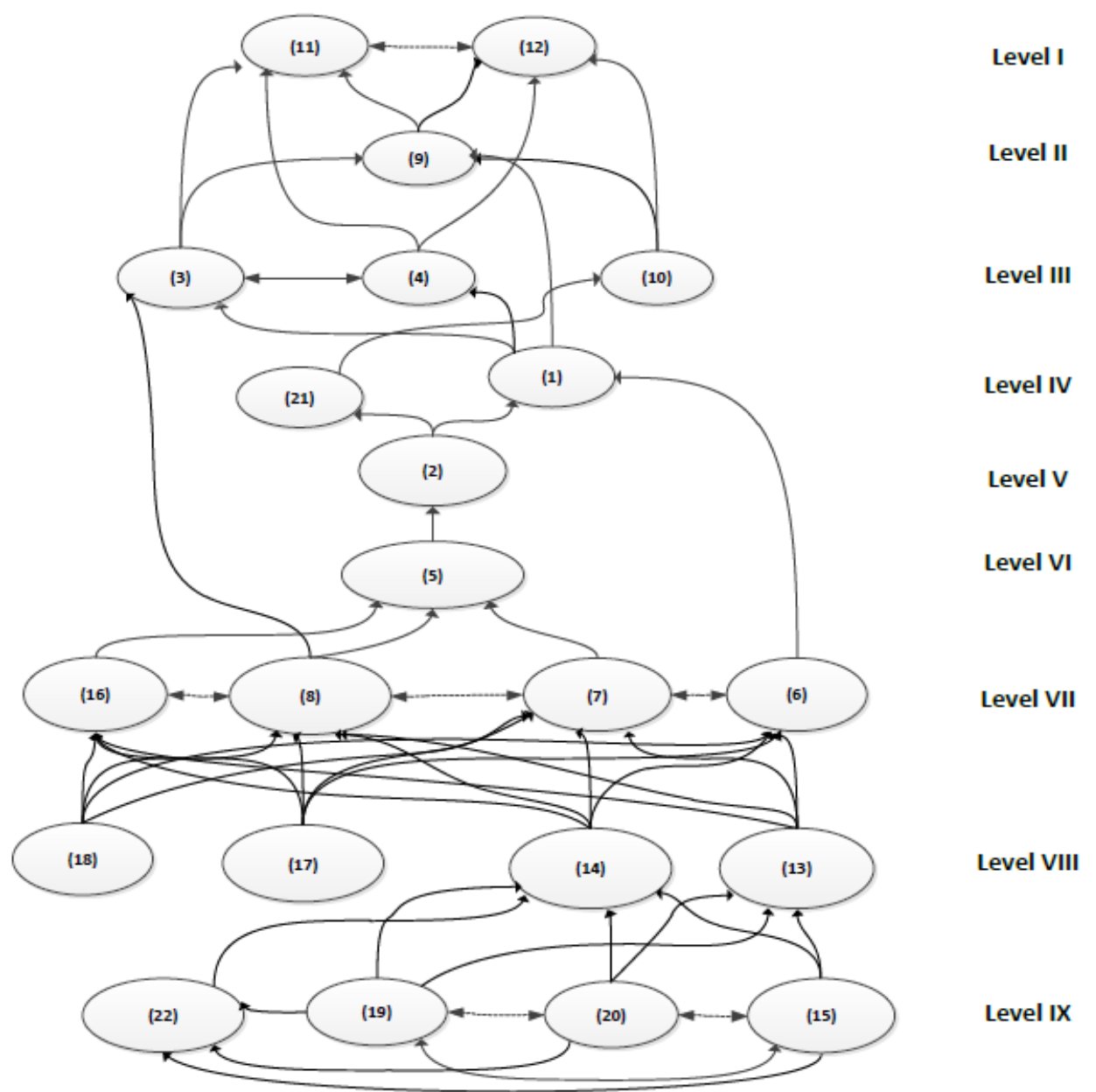

Fig. 2. The relation between influential Sub criteria of Mass Construction association's supply chain's agility

As we have already observed, sub criteria are presented in 9 levels. In the highest level of sub criteria graph, the variable "Customer's satisfaction" (11) and "Market sensitivity" (12) are situated. In the lowest level of sub criteria model, the variable "Regulations" (19), "Culture" (20), "Basic investment" (15) and "responsibility for social and environmental issues" (22) are observed and function as the base of this model. 
3.8. Classification of Criteria and sub criteria according to driver power and dependence power

\subsubsection{Classification of Criteria according to driver power and dependence power}

To classify the criteria according to driver and dependence power, variables should be subcategorized into four divisions according to driver and dependence power. In this study none of the criteria exists in the Autonomous variable group. Variables such as "Quality" (2), "Market"(4), and "Society" are in dependent variable group.

Table 11

Driving power and dependence power in reachability matrix for Criteria

\begin{tabular}{lllllllll}
\hline Criteria & 1 & 2 & 3 & 4 & 5 & 6 & 7 & 8 \\
\hline Driver power & 7 & 3 & 7 & 1 & 7 & 7 & 8 & 3 \\
Dependence power & 5 & 7 & 5 & 8 & 5 & 5 & 1 & 7 \\
\hline
\end{tabular}

Variables such as "Technology"(1), "Partnership"(3), "Information technology"(5), and "Financial"(6) are in the third group or Linkage variables that have strong driver and dependence power. The fourth group of variables are independent variables which perform as the base of the model and the system needs to emphasize first on them to begin its function. The variable "Government" (7) is in this group.

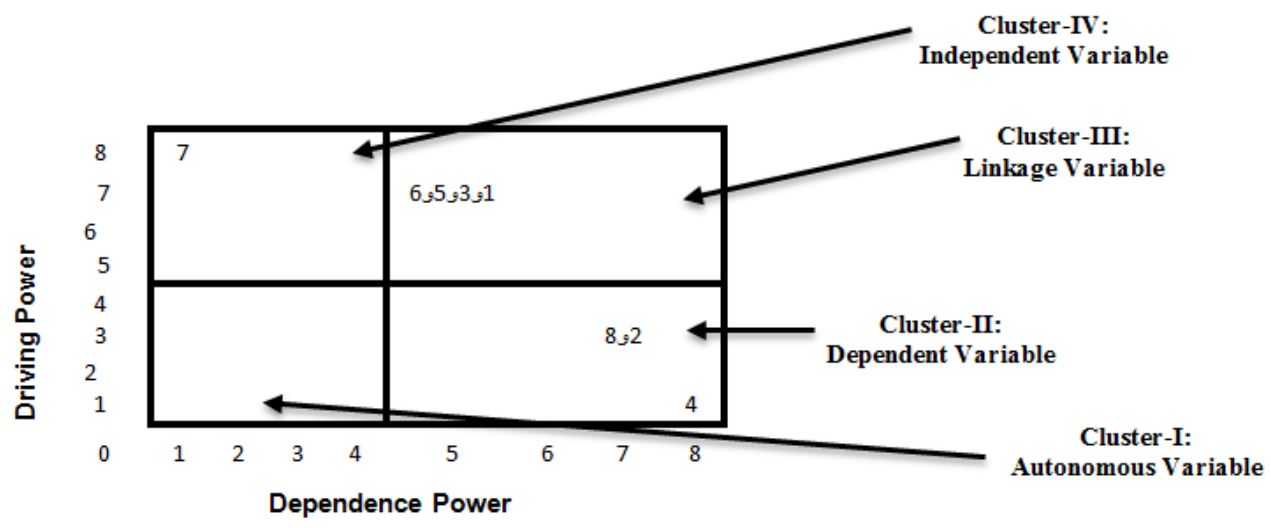

Fig. 3. Classification of Criteria according to driver power and dependence power

\section{Classification of sub criteria according to driver power and dependence power}

In classification the sub criteria according to driver power and dependence power, the first group consists of dependent variables and have weak driver and dependence power. None of the sub criteria exists in this group. In the second group, we have dependent variables that have weak driver power but strong dependence power. Variables such as "Time reduction" (1), "Manufacture and design improvement" (2), "Cost effectiveness" (3) , "Manufacturing quality" (4), "Production compatibility with designing" (5), "House cost" (9) , "House location" (10), "Customer's satisfaction" (11), and "house owners' level" (21) are in this group.

Table 12

Driving power and dependence in reachability matrix for sub criteria

\begin{tabular}{lllllllllllllllllllllllll}
\hline Sub criteria & 1 & 2 & 3 & 4 & 5 & 6 & 7 & 8 & 9 & 10 & 11 & 12 & 13 & 14 & 15 & 16 & 17 & 18 & 19 & 20 & 21 & 22 \\
\hline Driver Power & 6 & 9 & 5 & 5 & 10 & 14 & 14 & 14 & 3 & 4 & 2 & 2 & 15 & 15 & 20 & 14 & 15 & 15 & 20 & 20 & 5 & 16 \\
$\begin{array}{l}\text { Dependence } \\
\text { Power }\end{array}$ & 15 & 14 & 17 & 17 & 13 & 12 & 12 & 12 & 20 & 16 & 22 & 22 & 4 & 5 & 3 & 12 & 1 & 1 & 3 & 3 & 15 & 4 \\
\hline
\end{tabular}


The third group is the Linkage variable group, which has strong driver and dependence power. In this study the variables such as "Suppliers' strategic relation" (6), "Quick problem solving" (7), "Logistic flexibility" (8), and "On-time budget providing" (16) belong to this group. The fourth group consists of variables such as "Integrated information"(13), "Accurate and reliable information"(14), "Basic investigation"(15), “Clients' financial capacity"(17), "Contractors' financial capacity"(18), "Regulations"(19), "Responsibility for social and environmental issues" (22) and "Culture" (20) which have strong driver power but weak dependence power.

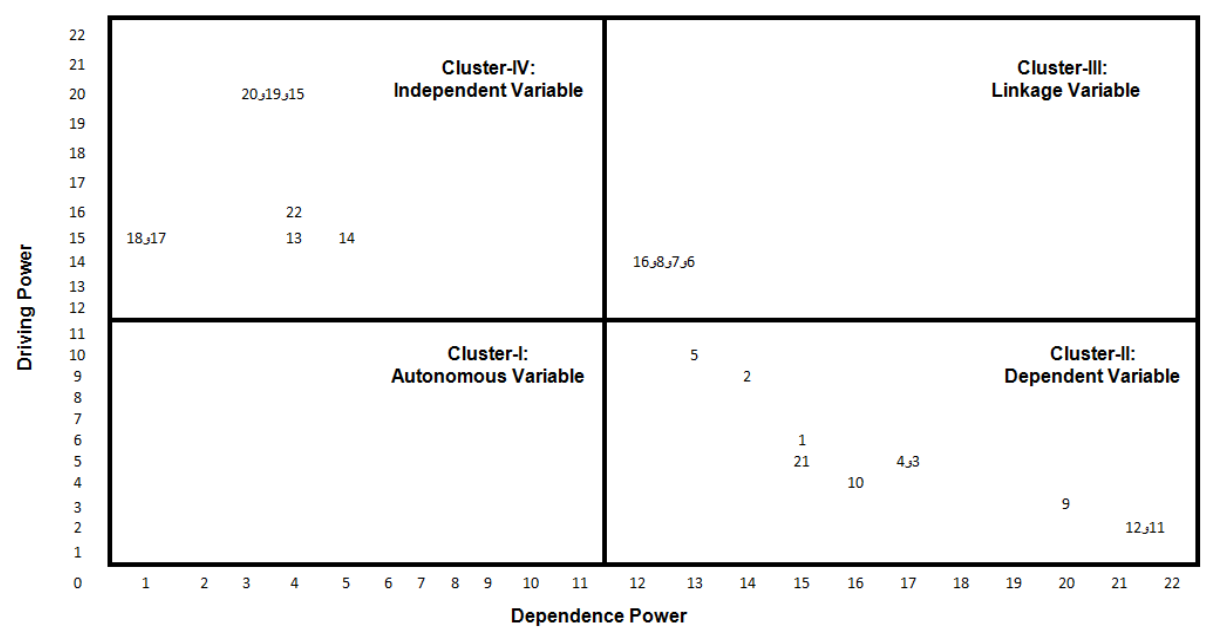

Fig. 4. Classification of Criteria according to driver power and dependence power

\section{Conclusions and Discussion}

$21^{\text {st }}$ century challenges have imposed pressures on competitive strength maintenance, production capabilities increase, production flexibility, price, services, quality, delivery, and its assurance, and forced them to re-establish and re-engineer their structure. Agility is connected to organizations' ability to survive in an unpredictable, unsteady and competitive environment. This ability is not only about flexibility and responsibility, but also about providing high quality productions with low cost and better services and delivery conditions. Although agility is a fundamental concept in management, there has not been a study related to agility in the realm of housing industry. This has caused the housing industry and other dependent industries encounter many predicaments. The reason of such problem is being unstable through quick changes.

Mass housing production associations must have enough attention to their supply chain so they will benefit from advantages of agile supply chain. Therefore, Mass Construction Associations need to recognize the aspects and agile sub criteria and their effect rate on each other to obtain the profits of agile supply chain. They also should be able to estimate their own agile supply chain. This study aims to represent the descriptions, classifications and needed aspects of agile supply chain in housing industry in order to begin a path to enrich agile supply chain theories in Iran.

In this study we sought to find the effective sub criteria and criteria of Mass Construction Associations' supply chain's agility, their relation, the key and basic factors of supply chain's agility, and to discover the sub criteria and criteria with strong drive and dependence power.

According to previous studies and experts' opinions, there are 8 criteria (society, government, information technology, market, partnership, quality and technology) and 22 sub criteria ("Time Reduction" (1), "Design and manufacture's improvement" (2), "Cost effectiveness" (3) , "Manufacturing quality" (4), "Production compatibility with designing" (5), "Suppliers' strategic relation" (6), "Quick problem solving" (7), "Logistic flexibility" (8) "House cost" (9) , "House location" (10), "Customer's satisfaction" (11), "market sensitivity”(12), "Integrated information"(13), "Accurate and reliable information"(14), "Basic investigation"(15), "On-time budget providing" 
(16), “Clients' financial capacity"(17), “Contractors' financial capacity" (18), "Regulations”(19), "House owners' level" (20), "Responsibility for environmental issues" (21) and "Culture" (22) are recognized for agility of Mass Construction Associations' supply chain. A mass housing production company must consider these sub criteria and criteria to achieve the agility in its supply chain.

This frame offers the managers a tool to be able to attentive towards unpredicted changes and benefit from opportunities. They should detect the elements, which help their organizations to adjust sudden changes. Hence, we use ISM technique to find the relations and consequences of criteria and the recognized sub criteria for Mass Construction Associations' supply chain's agility. The conclusions state that the criterion "Government"(7) is the basic and the most important element for supply chain agility in mass housing productions in Iran. This means that to achieve agility in a supply chain, "Government" should be assessed in supply chain which results in higher levels elements" investigation (such as "Society", "Government", "Financial", "Information technology", "Market", "Partnership", "Quality" and "Technology"). This process continues till the assessment of "market" is done.

An organization must have the 8 factors "Society", "Government", "Financial", "Information technology", "Market", "Quality", "Partnership" and "Technology" in an ideal level and should consider them in order to reach the agility to benefits from the advantages of agile supply chain. It can be said that sub criteria such as "Responsibility for social and environmental issues" (21), "Regulations" (19), "Culture" (20), and "Basic investigation" (15) are the most important so they must be investigated at first. The procedure continues till the investments of higher levels such as "Customer's satisfaction"(11), "Market sensitivity" (12) finishes. As mentioned before the criterion "Government" is the key criterion to obtain the agile supply chain. This criterion is in the lowest level (fourth level) and affects other four criteria in the third level ("Technology" (1), "Partnership" (3), "Financial"(6), and "Information technology" (5)). Also these criteria have mutual effects on each other and influence on two criteria in the second level ("Quality"(2), and "Society" (8)). These two also have mutual effect and influence on the criteria "Market" (4) in the first level which is the business target.

Four of sub criteria such as "Responsibility for social and environmental issues" (21), "Regulations"(19), "Culture"(20), "Basic investment(15) are in the lowest level (ninth level) and affect the sub criteria in eighth level ("Information integrity" (13), "Accurate and reliable information"(14), "Clients financial capacity"(17), "Contractors' financial capacity"(18)). These sub criteria affect the sub criteria in seventh level "Suppliers' strategic relation" (6), "Quick problem solving" (7), "Logistic flexibility" (8), "On-time budget providing" (16) which are influential on the sub criterion in the sixth level "Production compatibility with designing" (5). This sub criterion is effective on fourth level sub criteria that are "Time reduction"(1) and "House owners' level" (20). The sub criteria of fourth level influence the sub criteria of third level "House location"(10), "Production quality"(4), and "Cost effectiveness" (3) which have effect on sub criteria of second level "House cost". Finally all these sub criteria are influential on market sensitivity and customers' satisfaction.

According to determined Reachability set and Antecedent set which for each variable, variables can be subcategorized into 4 groups based on drive and dependence power. In this current study none of the sub criteria and criteria is in the independent group. The criteria such as "Quality", "Market", "Society", "Time reduction", Design and manufacture's improvement" , "Cost effectiveness", "Manufacturing quality", "Production compatibility", and "House cost" , "House location", "Customer's satisfaction", "House owners' level" are in this group which has the weak drive power but strong dependence power. 
The criteria such as "Technology", "Partnership", "Information technology", and "Financial" and the sub criteria such as "Suppliers' strategic relations", "On-time budget providing", "Quick problem solving", and "Logistic flexibility" are in the third group called group of linkage variables which have strong drive and dependence power. The fourth group that must be emphasized first, consists of criteria such as "Government", "Integrated information", "Accurate and reliable information", "Basic investment", "Clients' financial capacity", "Contractors' financial capacity", "Regulations", "Culture", and "Responsibility for social and environmental issues".

To increase agility of supply chain we should consider the dependence of sub criteria and criteria since there is no reflection in suppliers' quality when a slight change of sub criteria and criteria is made. These sub criteria and criteria must change simultaneously with other independent sub criteria and criteria and those from their own group. Therefore ISM model suggests the first emphasize should be on criterion "Government" and on sub criteria such as: "Regulations", "Culture", "Responsibility for social and environmental issues" and "Basic investigation".

The study's finding can be useful for managers who work in a complicated and dynamic environment and are willing to have agile supply chain. In this study, several points should be noted:

First: the importance of each factor depends on different situations. Various experts indicate various factors as the most important one, so a manager should have different consideration for the organization and work environment.

Second: factors' level is the result of ISM technique which represents the sequence of factors applied. Findings show that criteria such as "Government", "Regulations", "Culture", "Responsibility for social and environmental issues", and "Basic investigation" should be emphasized first in order to have agility in supply chain.

Third: none of the sub criteria and criteria is useless, they influence each other so any defect or neglect may result in damage and failure in the final conclusion (which are "Market sensitivity" and "Customer's satisfaction").

The survey result can be used by managers who seek to find agility in their organization's supply chain. In this study, literature review was used to identify the main factors in agile supply chain. Although identification could be done by factors' analysis, and it was not necessary to rely solely on literature review; by doing so we can detect more real factors according to our country's economical, political, social and cultural conditions. This study is the first study in the realm of agile supply chain in Mass Housing Production, while these kinds of studies can be applied to other industries through the development of statistical society in a particular industry. Moreover, the achieved model can be tested through path analysis to estimate the model's validity.

\section{Acknowledgements}

The authors would like to thank the Imam Khomeini International University of Qazvin (No. 75102291) for financial supports.

\section{References}

Agarwal, A., Shankar, R., \& Tiwari, M.K. (2006). Modeling the metrics of lean, agile and leagile supply chain: An ANP- based approach, European Journal of Operation Research, 173(1), 211-225.

Agarwal, A., Shankar, R., \& Tiwari, M.K. (2007). Modeling agility of supply chain. Industrial Marketing Management, 36, 443-445.

Alvandi, M., Fazli, S., \& Memarzade, M. (2011). E-Supplier selection using Delphi, fuzzy AHP and SIR. European Journal of Scientific Research, 66(4), 481-509. 
Baker, P. (2008). The design and operation of distribution centers within agile supply chain. International Journal of Production Economics, 111, 27-41.

Bal, J., Wilding, R., \& Goundry, J. (1999). Virtual teaming in the agile supply chain. International Journal of Logistics Management, 10(2), 71-83.

Beamon, B. M., \& Ware, T.M. (1998). A process quality model for the analysis, improvement and control of supply chain systems. Logistics Information Management, 11(2), 105-113.

Bruce, M., Daly, L., \& Towers, N. (2004). Lean or agile? a solution for supply chain management in the textiles and clothing industry?. International Journal of Operations \& Production Management, 24 (1), 151-170.

Carlson J., \& Yao A. (2008). Simulating an agile, synchronized manufacturing system. International Journal of Production Economics, 112, 714-722.

Chiristopher, M. (2000). The agile supply chain: competing in volatile markets. Industrial Marketing Management, 29, 37-44.

Chiristopher M., \& Jittner U. (2000). Developing strategic partnership in the supply chain: A practitioner perspective; European Journal of Purchasing and Supply Chain Management, 6(2), 117-127.

Chiristopher, M., \& Towill D.R. (2002). An integrated model for the design of agile supply chain; International Journal of Physical Distribution and Logistics, 31(4), 235-246.

Chiristopher M., \& Towill D. R. (2001). An integrated model for the design of agile supply chains. International Journal of Physical Distribution and Logistics, 31(4), 235-246.

Christopher M., Lowson R., \& Peck H. (2004). Creating agile supply chain in the fashion industry. International Journal of Retail \& Distribution Management, 32(8), 367-376.

Christopher, M. (2005). Logistics and Supply Chain Management. London: Prentice Hall.

Christopher, M. (1998) Logistics and supply chain management- Strategies for reducing cost and improving service, $2^{\text {nd }}$ ed., London et all.

Collin, J., \& Lorenzin, D. (2006). Plan for supply chain agility at Nokia: Lessons from the mobile infrastructure industry. International Journal of Physical Distribution \&Logistics Management, 36(6), 418-430.

Dove R. (1994-1996). Agile and otherwise. Series of articles on Agile Manufacturing Production Magazine. November 1994 to July 1996.

Dove, R. (1999). Knowledge management, response ability, and the agile enterprise. Journal of Knowledge Management, 3(1), 18-35

Fasial M. N., Banwet D.K., \& Shankar R. (2006). Supply chain risk mitigation: modeling the enablers. Business Process Management Journal, 12(4), 535-552.

Fazli S., Alvandi M., \& Poloie K. (2012), Identifying the relation between effective factors in evaluating the suppliers in electronic supply chain; An Interpretive structural modeling approach. Archives Des Sciences, 65(7), 381-391.

Giachetti, R. E., Martinez Luis, D., Sáaenz Oscar, A., \& Chen, C.S. (2003). Analysis of the structural measures of flexibility and agility using a measurement theoretical framework. International Journal of Production Economics, 86, 47-62.

Gunasekaran, A., Lai, K.H., \& Edwin Cheng, T.C. (2008). A competitive strategy in a networked economy. Omega, 36, $549-564$.

Gunasekaran A., Lai K.H., \& Cheng T.C. (2008). Responsive supply chain; Acompetitive strategy in a networked economy. Omega 36, 549-564.

Gunasekaran, A., McGaughey, R., \& Wolstencraft, V. (2001). Agile manufacturing: Concepts and framework, Agile Manufacturing: The 21st Century Competitive Strategy, Elsevier Science, 25-49.

Gunasekaran, A., \& Mcgaughey, R.E. (2001). TQM is supply chain management. The TQM Magazine, 15(6).

Gunasekaran, A., Patel, C., \& Tirtiroglu, E. (2001). performance measure and metrics in a supply chain environment. International Journal of Operations \& Production Management, 21(1/2), 71-87.

Gunasekaran, A., Patel, C., \& McGaughey, R. (2004). A framework for supply chain performance measurement. International Journal of Production Economics, 87, 333-347.

Hadar, M., \& Hader, S. (1995). Delphi und Kognitions Psychologie: Ein Zugang zur theoretischen Fundierung der Delphi-Methode, in: ZUMA-Nachrichten, 37(19). 
Helo, P., Xiao, Y., \& Jiao, R.J. (2006). A web-based logistics management system for agile supply demand network design. Journal of Manufacturing Technology Management, 17(8), 1058 - 1077.

Holweg M. (2005). The three dimensions of responsiveness. International Journal of Operations \& Production Management, 25(7), 603-622.

Hormozi, A.M. (2001). Agile manufacturing: the next logical step. Benchmarking an International Journal, 8(2), 132-143.

Hornby, A.S. (2000). Oxford advanced learners dictionary of current English, $6^{\text {th }}$ ed., oxford university press.

Huang J., Tzeng G., \& Ong Ch. (2005). Multidimensional data in Multidimensional scaling using the analytic network process. Pattern Recognition Letters, 26, 755-767.

Iacocca Institute. (1991). $21^{\text {st }}$ century manufacturing enterprise strategy; An industry Led View. 1(2 Iacocca Institute, Bethlem, PA.

Jain, V., \& Benyoucef, L. (2008). New Approaches for Modeling and Evaluating Agility in Integrated Supply Chains, INRIA Nancy Grand Est, COSTEAM Project, ISGMP, Bat. A, Ile du Saulcy 570000, Metz, France.

Jharkharia S., \& Shankar R. (2004). IT enablement of supply chains: modeling the enablers. International Journal of Productivity and Performance Management, 53(8), 700-712.

Kearney, A.T. (2002). How Governments Can Improve Public Sector Performance. LSE public policy group, London.

Khorshid, S. (2010). A hierarchical model based on fuzzy weighted average technique for evaluating and measuring manufacturing agility. Faslnameh Motaleat-e Modiriat-e sanati of Management \& Accounting School, 8(18), 41-69.

Kisperska- moron, D., \& Swierczek, A. (2008). The agile capabilities of polish companies in the supply chain: an empirical study. International Journal of Production Economics. 118(1), 217-224.

Lambert, D.M., Cooper, M.C., \& Pagh, J.D., (1998). supply chain management: implementation issues and research opportunities. The International Journal of Logistics Management 9(2). 1-9.

Lee H. L., So K. C., \& Tang C. S. (2000). Value of information sharing in a two level supply chain. Management Science, 46(5), 626-643.

Li, J.H., Alistair, R., Anderson, R., \& Harrison, T. (2003). The evolution of agile manufacturing. Business Process Management Journal, 9(2), 170-189.

Lin, CT., Chiu, H., \& Tseng, Y.H. (2006). Agility evaluation using fuzzy logic. International Journal of Production Economics, 101, 353-368.

Lin, C.T., Chiu, H., \& Chu, P.Y. (2006). Agility index in the supply chain. International Journal of Production Economics, 100(2), 285-299.

Mandal A., \& Deshmukh S.G. (1994). Vendor selection using interpretive structural modeling (ISM). International Journal of Operation \& production management, 14(6), 52-59.

Maskell, B. (2001). The age of agile manufacturing. Supply Chain Management: An International Journal, 6(1), 5-11.

Mason, A., Jones, R., Naylor, B., \& Towill, D. R. (2000). Lean, Agile or leagile? Matching your supply chain to the marketplace. International Journal of Production Research, 38(17), 4061-4070.

Mason, S.J., Cole, M. H., Ulrey, B.T., \& Yan, L. (2002). Improving electronics manufacturing supply chain through outsourcing. International Journal of Physical Distribution and Logistics Management, 32(7), 610-620.

Memarzade, M. (2012). Comparing two combined methods; Delphi, Fuzzy AHP, SIR and Delphi, Fuzzy AHP, Fuzzy VIKOR to rank suppliers in electronic Supply chain (Case study: SAIPA Corporation). The thesis presented of the degree of Master of Science in management (production). Imam Khomeini International University.

Meredith, S., \& Francis, D. (2000). Journey towards agility: the agile wheel explored. The TQM Magazine, 12(2), 137-143.

Oloruntoba, R., \& Gray, R. (2006). Humanitarian aid: an agile supply chain? Supply Chain Management: an International Journal, 11(2), 115-120.

Power D., Sohal A., \& Rhaman S. (2001). Critical success factors in agile supply chain management. International Journal of Physical Distribution \& Logistics Management, 31(4), 247-265. 
Ramesh, G., \& Devadasan, S. (2007). Literature Review on the agile manufacturing criteria. Journal of Manufacturing Technology Management, 18(2), 182-201.

Ravi V., \& Shankar R. (2005). Analysis of interactions among the barriers of reverse logistics. Technological Forecasting and Social Changes, 72, 1011-1029.

Ravichandran, T. (2007). IT Competencies, Innovation Capacity and Organizational Agility: Performance Impact and the Moderating Effects of Environmental Characteristics- Lally School of Management \& Technology Rensselaer Polytechnic Institute-Submitted to CIST, INFORMS.

Rigby C., Day M., Forrester P, \& Burnett J. (2000). Agile supply: Rethinking systems thinking, Systems practice. International Journal of Agile Management Systems, 2(3), 178-186.

Sharifi, H., \& Zhang, Z. (1999). A methodology for achieving agility in manufacturing organization. International Journal of Production Economics, 62, 7-22.

Sharifi, H, \& Zhang, Z. (2001). Agile manufacturing in practice - Application of a methodology. International Journal of Operations \& Production Management, 21(5/6), 772 - 794.

Sherehiy, B., Karwowski, W., \& Layer, J. (2007). A review of enterprise agility: concepts, frameworks, and attributes. International Journal of Industrial Ergonomics, 37, 445-460.

Simchi- Levi, D., Kaminski, P., \& Simchi-levi E. (2000). Designing and managing the supply chain, concepts, strategies and case studies. Irwin McGraw- Hill Higher Education, international edition.

Stadtler, H., \& Kilger, C. (2005). Supply Chain Management and Advanced Planning: Concepts, Models, Software and Case Studies. $4^{\text {th }}$ ed.

Sterling J. D. (2008). Organizational Agility-The Association for Laboratory Automation. Journal of Laboratory Automation, 13(6), A12 doi:10.1016/j.jala.2008.09.002

Stratton R., \& Warburton R.D.H. (2003). The strategic integration of agile and lean supply. International Journal of Production Economics, 85, 183-198.

Svensson G. (2001). Perceived trust towards suppliers and customers in supply chains of the Swedish automotive industry. International Journal of Physical Distribution and Logistics Management, 31(9), 647-662.

Swafford P. M., \& Ghosh S. (2006). Murthy M. the antecedents of supply chain agility of a firm: scale development and model testing. Journal of Operation Management, 24, 170-188.

Swafford, P.M. (2003) Theoretical development and empirical investigation of supply chain agility. PHD dissertation in Dupree collage of management, Georgia Institute of Technology.

Tam, C.-M., \& Tong, T. (2008). Locating large-scale harbour-front project developments using SIR method with grey aggregation approach. Construction Innovation, 8, 120-136.

Teece D. J., Pisano G., \& shuen A. (1997). Dynamic capability and strategic management. Strategic Management Journal, 18(7), 509-533.

Tolon W. J. (2000). Virtual situation room: connecting people across enterprises for supply chain agility. Computer Aided Design, 32, 109-117.

Van Hoek, R. (2001). Epilogue: moving forward with agility. International Journal of Physical Distribution \& Logistics Management, 31(4), 289-307.

Van, H., Harrison, A., \& Chiristopher, M. (2001). Measuring agile capabilities in the supply chain. International Journal of Operation \& Production Management, 21(1/2), 4061-4070.

Warfield, J. N. (1978). Societal Systems: Planning, Policy, and Complexity. New York: Wiley Interscience.

Warfield, J.N. (1974). Toward interpretation of complex structural modeling; IEEE Transaction Systems Man Cybernetic, 4(5), 405-417.

Wong, C.Y., Arlbjørn, J.S., Hvolby, H.H., \& Johansen, J. (2006). Assessing responsiveness of a volatile and seasonal supply chain: A case study. International Journal of Operations \& Production Management, 104(2), 709-721.

Yusuf, Y.Y., Sarhadi, M., \& Gunasekaran, A. (1999). Agile manufacturing: The drivers, concepts, and attributes. International Journal of Production Economics, 62, 33-43. 